\title{
Pemberdayaan Masyarakat Melalui Pelatihan Berbagai Olahan Jantung Pisang Di Desa Pabbarasseng Kecamatan Bua Kabupaten Luwu
}

\section{Intisari $^{1}$ dan Rosnina ${ }^{2}$}

1Email : intisarilatief@gmail.com

Prodi Agribisnis, Fakultas Pertanian Unanda

2Email : rosninabonebone@yahoo.com

Prodi Agribisnis, Fakultas Pertanian Unanda

\begin{abstract}
Abstrak. Tersedianya sumberdaya, haruslah dibarengi dengan kemampuan mengolah sumberdaya tersebut sehingga menghasilkan sesuatu yang lebih berdayaguna, memiliki nilai tambah dan bernilai jual/ ekonomi, oleh karena itu, sangat penting membekali diri dengan ilmu pengetahuan dan keterampilan. Jantung pisang bukanlah bahan pangan yang susah ditemui di Di Desa Pabbarasseng dan sekitarnya. Tetapi kebanyakan masyarakatnya hanya memanfaatkan jantung pisang sebagai sayuran yang menemani makan atau sarapan keluarga. Padahal jantung pisang ini jika diolah dengan lebih kreatif dan inovatif maka dapat dijadikan sebagai sajian istimewa di rumah dan menjadi mata pencaharian tambahan bahkan utama jika ditekuni dengan serius. Oleh karena itu, perlu adanya penyuluhan dan pelatihan berbagai olahan jantung pisang bagi wanita yang ada di Desa Pabbarasseng serta pelatihan kewirausahaan untuk peningkatan kesejahteraan masyarakat. Tujuan dari kegiatan ini bertambahnya pengetahuan dan keterampilan masyarakat di Desa Pabbarasseng Kecamatan Bua Kabupaten Luwu tentang pengolahan jantung pisang. Metode pelaksanaan kegiatan ini yaitu : (1) Sosialisasi program ke mitra, (2) Penyuluhan dan Pelatihan Berbagai Olahan Jantung Pisang, (3) Pelatihan Kewirausahaan, dan (4) Pendampingan.
\end{abstract}

Kata Kunci: Olahan Jantung Pisang, Pengabdian Masyarakat, Kewirausahaan

\section{PENDAHULUAN}

Pabbarasseng adalah salah satu desa di Kecamatan Bua yang merupakan hasil pemakaran dari Desa Baroa pada Tahun 2008. Masyarakat di Desa Pabbarasseng sebagian besar bermatapencaharian sebagai nelayan, dan petani rumput laut sebagai tambahan pekerjaan. Pendapatan mereka sangat ditentukan oleh hasil produksi pertanian yang dihasilkan karena berbagai faktor lain yang mempengaruhi diantaranya alat yang masih bersifat tradisional, lahan pertanian yang begitu sempit sehinnga para petani tidak dapat menghasilkan produksi yang melimpah. Hal ini akan mempengaruhi pada pemenuhan kebutuhan hidup keluarga terutama pemenuhan pangan secara layak dalam jumlah maupun kualitas sulit tercapai. Dampak yang ditimbulkan oleh terbatasnya jumlah dan kualitas pangan yang dikonsumsi oleh keluarga petani adalah tidak tercukupinya kebutuhan makanan pada anggota keluarga.

Kurangnya pemahaman dan kesadaran untuk menghasilkan kreativitas dan inovasi, menyebabkan banyaknya sumberdaya yang tidak terolah maksimal, yang dapat menjadi ladang untuk menambah pendapatan keluarga. Seperti yang dikatakan oleh Alma (2018), bahwa inovasi 
selalu membawa perkembangan dan perubahan ekonomi. Inovasi bukan hanya suatu temuan yang luar biasa, tetapi suatu temuan yang menyebabkan berdayagunanya sumber ekonomi ke arah yang lebih produktif.

Bahan pangan yang biasa saja akan memiliki nilai lebih ketika di olah atau dihidangkan dengan cara tertentu, seperti yang dikatakan oleh Sediaoetama (2004), bahwa masyarakat memberi nilai sosial berbeda-beda kepada suatu jenis makanan dan bahan makanan tertentu. Bahan dasar pangan tertentu mungkin mempunyai nilai sosial rendah, tetapi nilai ini menjadi meningkat bila diolah atau dihidangkan dengan cara tertentu. Siswono (2002) mengatakan bahwa kebosanan dapat dicegah terhadap produk yang bahan dasarnya sama bila disajikan dengan bentuk, citarasa, dan penampilan yang berbeda.

Jantung pisang adalah bunga yang dihasilkan oleh pokok pisang (Musa spp) yaitu sejenis tumbuhan dari keluarga Musacea uang berfungsi untuk menghasilkan buah pisang. Jantung pisang dihasilkan semasa proses pisang berbunga dan menghasilkan tandan pisang sehingga lengkap. Struktur jantung pisang mempunyai banyak lapisan kulit dari yang paling gelap coklatungu kemerahan dibagian luar dan warna putih krim susu dibagian dalam. Terdapat susunan bunga berbentuk jejari diantara kulit tersebut dan ditengahnya yang lembut.

Serat pangan jantung pisang bermanfaat untuk memperlambat pencernaan usus, sehingga aliran energi ke dalam tubuh menjadi tetap; memberikan perasaan kenyang yang lebih lama; memperlambat kemunculan gula darah (glukosa), sehingga insulin yang dibutuhkan untuk mengubah glukosa menjadi energi semakin sedikit; membantu mengendalikan berat badan dengan memperlambat munculnya rasa lapar; dan meningkatkan produksi ASI karena kandungan laktogogum yang menstimulasi produksi oksitosin dan prolactin.

Jantung pisang mudah ditemukan dan masyarakat biasa menjadikannya sebagai sayur. Jantung pisang dapat dijadikan berbagai bahan pangan yang enak dan menyehatkan, baik sebagai pengganti lauk ataukah dijadikan sebagai cemilan. Jantung pisang dapat dijadikan sebagai pengganti protein seperti pengganti daging ayam, daging sapi dan lain sebagainya sehingga dapat mengurangi pengeluaran. Adapun olahan dari jantung pisang seperti nugget, bakso, gulai, bakwan, dan abon.

Berdasarkan hasil survei, masyarakat di Desa Pabbarasseng sebagian besar bermatapencaharian sebagai nelayan, dan petani rumput laut. Kegiatan tersebut dilakukan oleh laki-laki, sedangkan wanita atau ibu rumah tangga membantu ketika panen rumput laut terutama dalam proses pembersihan dan penjemuran, sehingga dalam waktu antara penanaman dan waktu panen, tidak memiliki pekerjaan lain selain mengurus rumah tangga dan duduk bercengkrama dengan sanak saudara, keluarga atau tetangga. Waktu yang senggang ini harusnya dimanfaatkan dengan baik, di samping mengurus rumah tangga, juga dapat memanfaatkan waktu senggang dengan hal yang lebih bermanfaat.

Tersedianya sumberdaya, haruslah dibarengi dengan kemampuan mengolah sumberdaya tersebut sehingga menghasilkan sesuatu yang lebih berdayaguna, memiliki nilai tambah dan 
bernilai jual/ekonomi, oleh karena itu, sangat penting membekali diri dengan ilmu pengetahuan dan keterampilan. Jantung pisang bukanlah bahan pangan yang susah ditemui di Di Desa Pabbarasseng dan sekitarnya. Tapi kebanyakan masyarakatnya hanya memanfaatkan jantung pisang sebagai sayuran yang menemani makan atau sarapan keluarga. Padahal jantung pisang ini jika diolah dengan lebih kreatif dan inovatif maka dapat dijadikan sebagai sajian istimewa di rumah dan menjadi mata pencaharian tambahan bahkan utama jika ditekuni dengan serius. Oleh karena itu, perlu adanya penyuluhan dan pelatihan berbagai olahan jantung pisang bagi wanita yang ada Di Desa Pabbarasseng serta pelatihan kewirausahaan untuk peningkatan kesejahteraan masyarakat.

\section{METODE PELAKSANAAN}

Metode pelaksanaan kegiatan Program Kemitraan Masyarakat Stimulus (PKMS) yang akan diadakan di Desa Pabbarasseng Kabupaten Luwu, yaitu meliputi (1) Sosialisasi program ke mitra, (2) Penyuluhan dan Pelatihan Berbagai Olahan Jantung Pisang, (3) Pelatihan Kewirausahaan, (4). Pendampingan.

\section{HASIL DAN PEMBAHASAN}

Kegiatan program kemitraan masyarakat stimulus (PKMS) ini dilaksanakan di Desa Pabbarasseng Kecamatan Bua Kabupaten Luwu, khususnya wanita dan ibu rumah tangga. Mitra berperan aktif dalam setiap tahapan dalam kegiatan ini mulai dari tahap sosialisasi sampai pada aplikasi di lapangan. Kegiatan ini juga melibatkan beberapa mahasiswa, dan jumlah mitra dalam kegiatan ini adalah 20 orang wanita dan atau Ibu rumah tangga. Kegiatan ini dilaksanakan dengan tahapan sebagai berikut:

(1) Sosialisasi program ke mitra.

Tim pelaksana memperkenalkan kegiatan PKMS ke mitra dan memberikan gambaran tentang kegiatan yang akan dilaksanakan sehingga mitra dapat memahami dengan baik dan nantinya dapat berperan aktif di semua tahapan kegiatan.
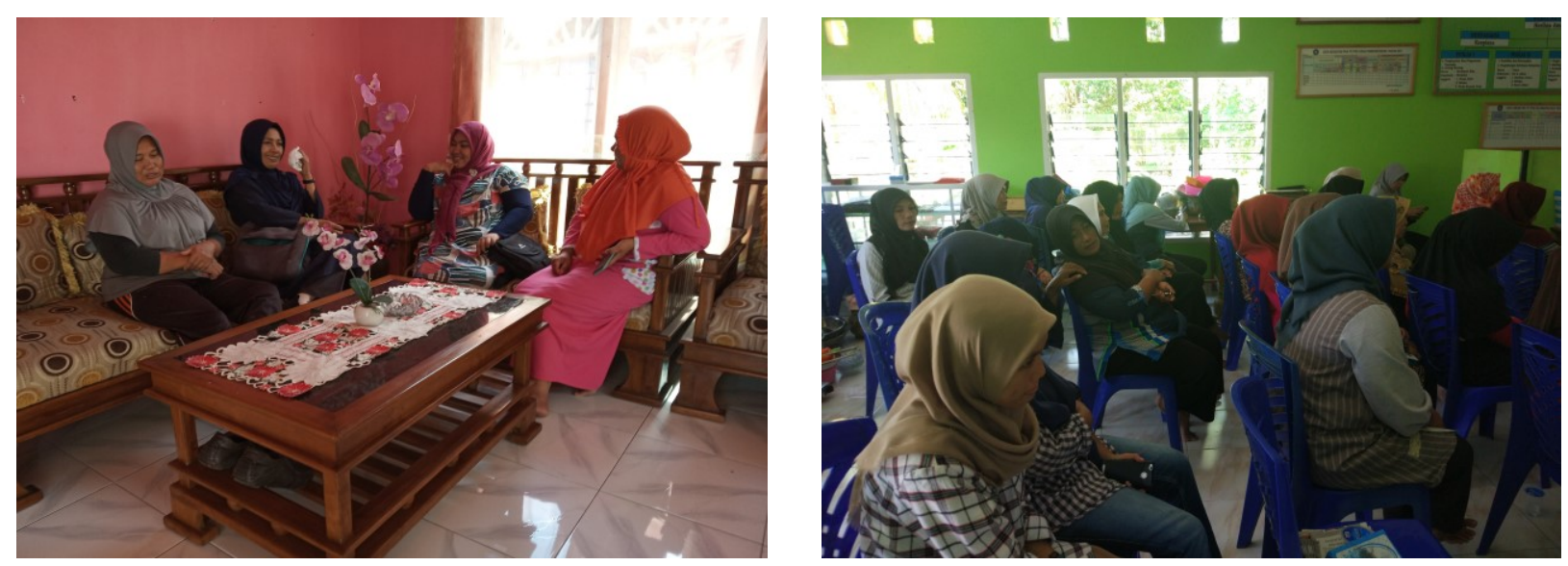

Gambar 1. Sosialisasi dengan ketua dan masyarakat mitra 
(2) Penyuluhan dan Pelatihan Berbagai Olahan Jantung Pisang.

Penyuluhan dan pelatihan pada kegiatan ini, menempatkan mitra sebagai subyek pendidikan, sementara tutor berperan sebagai fasilitator. Yang aktif belajar adalah para peserta, sehingga dalam pelaksanaan materi teoritis hanya diberikan sebagai pengantar, dilanjutkan dengan pelatihan. Mitra yang telah mengikuti penyuluhan akan dibagi beberapa kelompok mitra kemudian mempraktikan berbagai olahan jantung pisang. Adapun pengolahan jantung pisang yang dipraktekkan adalah bakso jantung pisang, nugget jantung pisang, gulai jantung pisang dan abon jantung pisang.
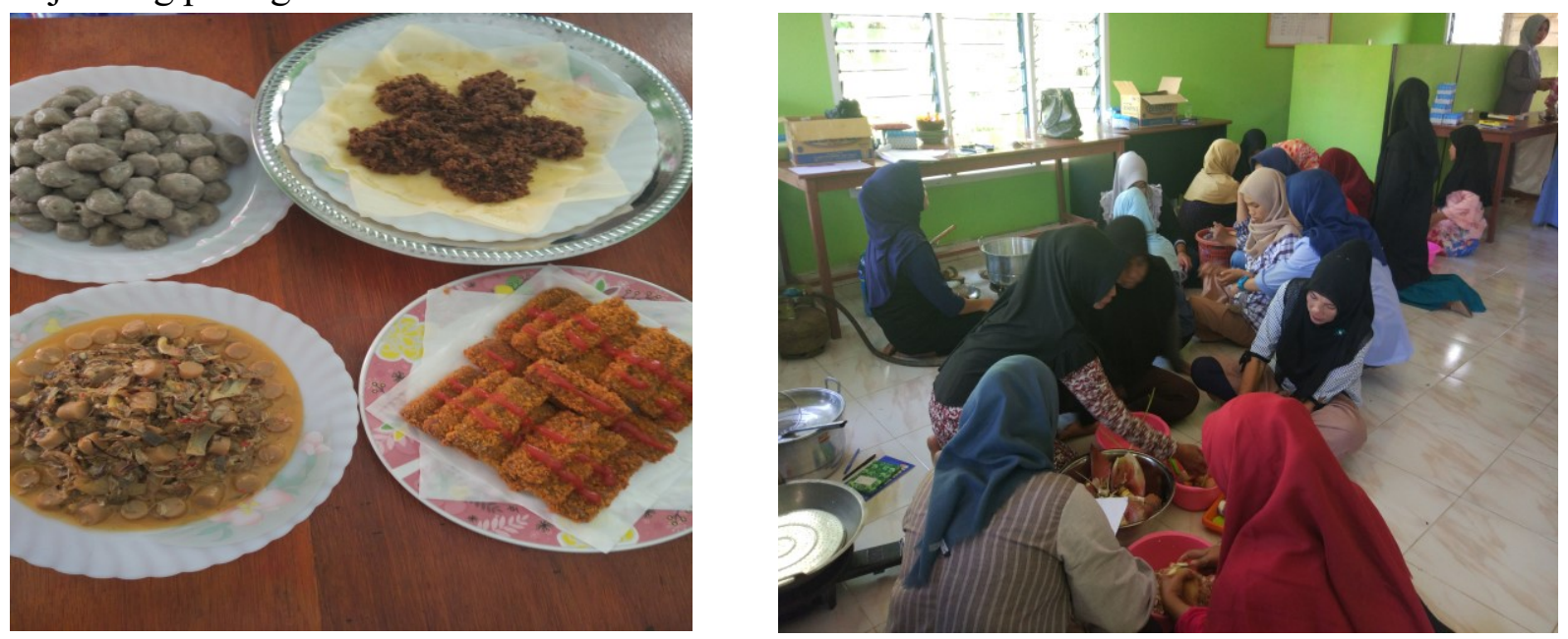

Gambar 2. Pelatihan berbagai olahan jantung pisang (abon, bakso, nugget, dan gulai)

(3) Pelatihan Kewirausahaan.

Materi pelatihan kewirausahaan meliputi motivasi berwirausaha, kemasan, dan pemasaran yang efektif. Hal ini dilakukan untuk dapat menambah wawasan tentang kewirausahaan dan menjadi stumulus sehingga termotivasi untuk berwirausaha. Kegiatan ini telah dipublikasikan di media cetak.
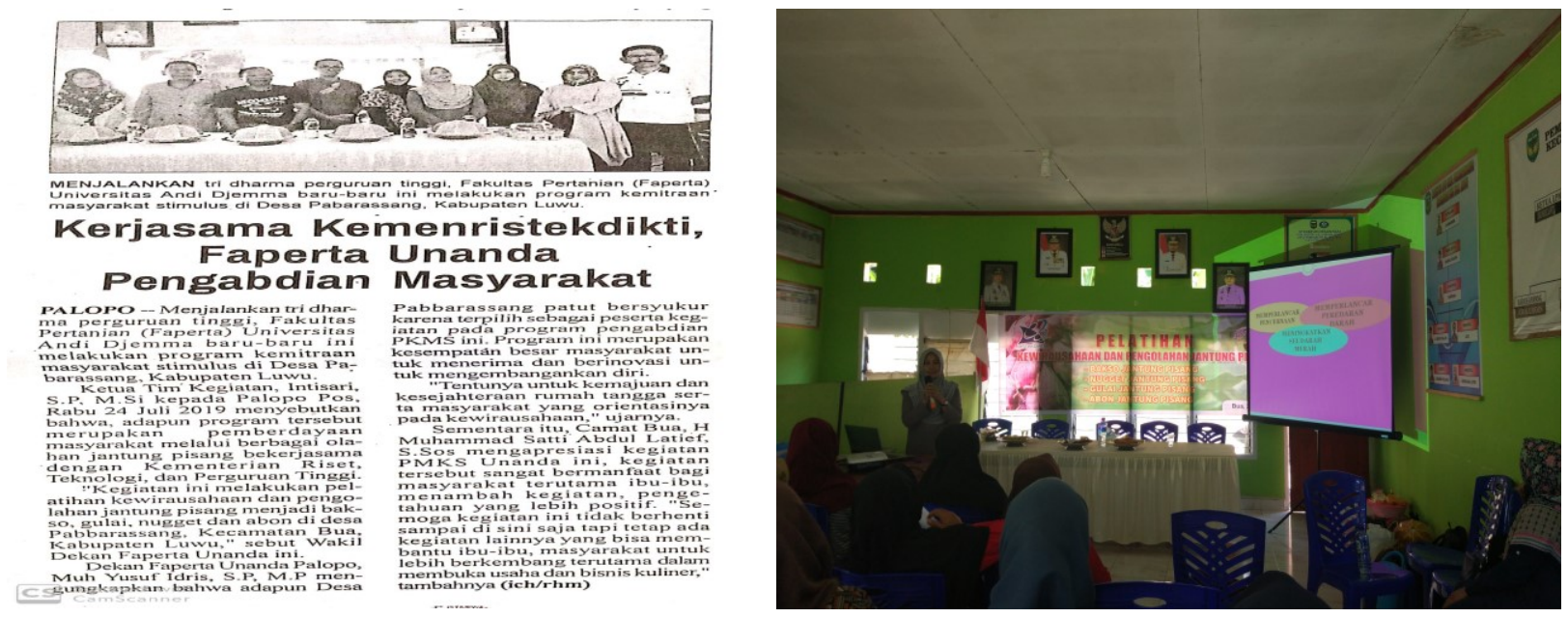

Gambar 3. Pelatihan kewirausahaan dan publikasi kegiatan di media cetak 
(4). Pendampingan.

Pendampingan dilakukan selama pelaksanaan program. Diharapkan mitra dapat membagi ilmu ke masyarakat yang lain. Untuk memantau dan mengevaluasi penerapan dari program ini, mitra tetap mendapatkan bimbingan oleh tim pelaksana program melalui kegiatan pendampingan sekaligus sebagai tempat konsultasi bagi mitra jika mereka mengalami kesulitan dalam menjalankan tahapan kegiatan PKMS.
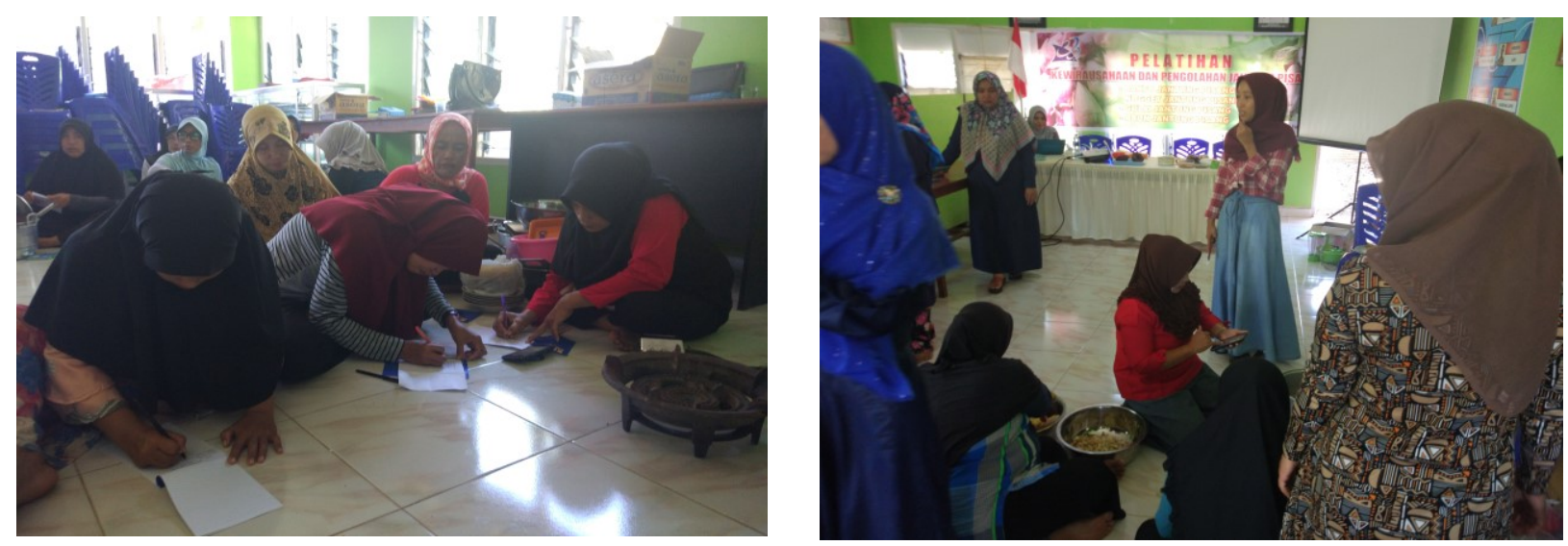

Gambar 4. Pendampingan

Selanjutnya diharapkan mitra dapat melakukannya secara partisipatif atau mandiri dengan membagi ilmu kepada masyarakat yang lain sehingga kegiatan ini dapat berlanjut dan berkesinambungan.

\section{SIMPULAN}

Kegiatan pengabdian masyarakat yang dilakukan dapat menambah pengetahuan dan keterampilan warga tentang bagaimana mengolah jantung pisang menjadi berbagai olahan yang memiliki nilai tambah sehingga ke depan bisa dijadikan alternatif usaha.

\section{UCAPAN TERIMA KASIH}

Ucapan terima kasih kepada Kemenristek Dikti untuk pendanaan kegiatan ini melalui Program Kemitraan Masyarakat Stimulus (PKMS) Tahun Anggaran 2019.

\section{DAFTAR PUSTAKA}

Alma Buchari. 2018. Kewirausahaan (untuk mahasiswa dan umum). Alfabeta, Bandung Sediaoetama A.D., 2004. Ilmu Gizi. Jilid Dua. Dian Rakyat, Jakarta Siswono. 2002. Kembali ke Pola Makan yang Benar, www.google.com Intisari. 2007. Upaya Pengembangan Bauran Pemasaran Kue bagea Melalui Analisis Sikap dan Faktor Sosial Ekonomi Konsumen (Tesis). Program Pasca Sarjana Universitas Hasanuddin, Makassar.

Sumarwan, Ujang. 2004. Perilaku Konsumen (Teori dan Penerapannya dalam Pemasaran). Ghalia Indonesia, Bogor 
To Maega, 2(2), Agustus 2019 | 36 